\title{
4 \\ Sport and the European Court of Justice
}

The ECJ is an important agenda setter. Court rulings play an important part in defining the content of the EU's systemic agenda and the conditions under which an issue is transferred to the institutional agenda for active policy development. The ECJ's line of reasoning in relation to sport has been developed within the context of a number of important institutional relationships. As such, the ECJ's role in establishing the boundaries of EU sports regulation is not deterministic.

In Walrave, Donà and Heylens, the ECJ established important principles concerning the relationship between sport and EU law. ${ }^{1}$ In the event, the lack of enforcement from the Commission limited the scope of these rulings. In Bosman, the principles established in previous case law were extended. As the Commission was more energetic in enforcing Bosman, so the ruling took on enormous legal significance for sport. ${ }^{2}$ The rulings in Deliege and Lehtonen, which placed some limit on the application of EU law to sport, took place in the context of an on-going political discussion within the EU on how to reconcile EU law with sports social significance. ${ }^{3}$ Whereas Walrave, Donà, Heylens and Bosman took place in an environment where the construction of the Single Market was seen as paramount, Deliège and Lebtonen reflected greater sensitivity to the socio-cultural dimension of European integration. Deliège and Lehtonen therefore represent the ECJ's contribution to the construction of the separate territories.

This chapter examines the ECJ's sports-related jurisprudence in six parts. The first part reviews the role of the ECJ in the process of European integration. The second examines the Treaty provisions relating to the free movement of workers and the right of establishment and the freedom to provide services. The third section analyses the significance of the ECJ rulings in Walrave, Donà and Heylens. Section four examines the impact of the Bosman ruling and section five reviews the case law in Deliège and Lebtonen. The final section draws some conclusions. 


\section{The European Court of Justice and European integration}

Most writers agree that the ECJ's activities have made an important contribution to European integration. The ECJ has successfully extended the scope of EU law through the establishment of the principles of direct effect and supremacy. ${ }^{4}$ This has equipped the ECJ (supported by national courts and individual litigants) to develop substantive law in the field of the free movement of goods, labour, services and capital. Whilst the influence of the ECJ on these issues is not questioned, no consensus exists on how and why the ECJ has been able to achieve this. A vibrant debate has ensued enriching both political science and law. Distilling the essentials of this debate, four broad approaches can be identified.

Activism The first approach sees the ECJ as an autonomous political actor seeking to strategically advance its own position and European integration in a manner consistent with its belief system. Not all writers agree that this has had a positive impact on integration (see for example Weiler 1981 and Rasmussen 1986). In particular judicial activism contributed not only to a reluctance of the member states to integrate through supranational channels, but also to disruptions and blockages in the EU's political decision-making process. Other writers have been more positive on the effect of ECJ jurisprudence on integration. Burley and Mattli have argued that the ECJ has incrementally constitutionalised the Treaty of Rome, a process that has 'laid the foundations for an integrated European economy and polity' (Burley and Mattli 1993). Adopting a neo-functional analysis, Burley and Mattli argue that law has spilled over from the purely economic sector to new spheres, including new policy areas such as occupational health and safety, social welfare and education. Just as Haas argued economics acted as a mask for political integration, so Burley and Mattli argue law acts as a mask for politics. Furthermore, this mask is protected by a shield that insulates the ECJ from political interference. This is because policy makers view law as technical and the ECJ couches its judgments in apolitical terms. In addition to analysing economic to political functional spillover, Burley and Mattli examine functional spillover in terms of legal principles. To illustrate this point the relationship between the Van Gend and Loos case and the Costa v. Enel case is examined. ${ }^{5}$ Once the principle of direct effect was established by the ECJ, it became necessary and indeed logical to establish the principle of supremacy. Without supremacy, direct effect could not be fully realised, an example of incomplete integration. Burley and Mattli also detect a strong political spillover dimension in the work of the ECJ. In particular, they detect a bottom-up shift in expectations and responses to cases from member governments, national courts and individual litigants. The preliminary reference procedure assists this connection between legal jurisdictions. ${ }^{6}$ 
Legalism The second approach rejects the notion of judicial activism. The ECJ operates above politics and simply applies the law in a neutral manner consistent with the role ascribed to it under the Treaty. If the ECJ has advanced integration through its jurisprudence, it has done so in a manner consistent with the pro-integrative logic of primary and secondary legislation.

Intergovernmentalism The third approach (very broadly referred to here as intergovernmentalism) also rejects the idea of a judicially active and autonomous ECJ. ECJ rulings reflect the interests of the member states and do not run contrary to them. If they did, member states hold the power of sanction over the ECJ through the revision of the Treaty, which could alter the structure and role of the Court (see for instance Garrett and Weingast 1993). Occasionally governments may be prepared to accept short-term losses in order to secure wider long-term gains. This interpretation accounts for instances where ECJ rulings appear to run contrary to member states interests, yet the governments do not retaliate.

Multi-level governance The final broad interpretation (and one consistent with the approach adopted in this text) seeks to locate the ECJ's contribution to European integration in a wider context. For example, Wincott claims that whilst it is misleading to see the ECJ as an institution that has forced or engineered integration it is similarly misguided to see the ECJ as an agent of the member states (Wincott 1996: 170-184). Wincott claims 'an analysis which attributes a rational and synoptic control of European integration to a single institution or group is likely to be misleading' (Wincott 1996: 170). As such, even though the ECJ has had an impact on European integration, it remains one actor among many. For example, the ECJ is dependent on a number of relationships in order for it to advance integration.

- ECJ-member state The ECJ's role in the integration process was initially sanctioned by the member states and can be changed through Treaty revision. Furthermore, the member states can exploit a number of venues in order to limit the impact of past and future ECJ rulings. Changes to secondary legislation agreed by the Council of Ministers represent the most formal method, although political pressure can be imparted on the ECJ through soft law measures. Political Declarations released as annexes to Treaties or in the form Presidency Conclusions are often influential. In the case of pension rights, the member states added a protocol (the Barber Protocol) to the Maastricht Treaty preventing the retroactive application of the ruling. It has been noted that following the protocol, the ECJ 'moderated its activism in this area' (Hix 1999: 128).

- ECJ-European Parliament Given the expansion of the European Parliament's legislative capabilities, the ECJ has the potential to be 
influenced by legislation agreed jointly between the Council and the Parliament.

- ECJ-Commission The ECJ has formed a close supranational alliance with the Commission. For instance in terms of widening the scope of the free movement of goods principle, the Commission made legislative use of the ECJ's Cassis judgement. In relation to gender equality, the ECJ played a crucial role in giving expression to the Commission's calls for the implementation of Article 141 (Wincott 1996). Furthermore, the emergence of a merger control policy demonstrates the interplay between judicial and legislative actions (Bulmer 1994).

- ECJ-national courts Without the support of national courts, the ECJ would have been unable to develop many of the legal principles which today define the EU's legal order. Article 234 creates a bridge between the two legal orders by allowing national courts to seek guidance from the ECJ. This procedure has allowed the ECJ to issue preliminary rulings on the correct interpretation of EU law.

- ECJ-individual The principle of direct effect has enabled individual litigants to defend their rights under EU law before national courts. Individuals, including companies, therefore have a stake in the EU's legal order and in this capacity are supported by lawyers.

Whilst therefore the ECJ plays an important role in developing legal principles and substantive law, its role should be placed in context. The ECJ constrains and is constrained by multiple actors operating within the EU's legal community. The development of new substantive areas of EU policy results from a complex interplay of forces involving many actors. The ECJ's role in sports regulation illustrates these complexities.

\section{Free movement in the European Union}

Article 3(c) of the Treaty requires 'the abolition, as between member states, of obstacles to the free movement of goods, persons, services and capital'. According to Article 12, for this to be achieved, 'any discrimination on grounds of nationality shall be prohibited'. Three further Articles elaborate this goal in the specific fields of employment (Article 39), establishment rights (Article 43) and service provision (Article 49).

The free movement of workers

Article 39 provides for:

1 Freedom of movement for workers shall be secured within the Community.

2 Such freedom of movement shall entail the abolition of any discrimination based on nationality between workers of the member states as regards employment, remuneration and other conditions of work and employment.

3 It shall entail the right, subject to limitations justified on grounds of public policy, public security or public health: 
a to accept offers of employment actually made;

b to move freely within the territory of member states for this purpose;

c to stay in a member state for the purpose of employment in accordance with the provisions governing the employment of nationals of that State laid down by law, regulation or administrative action;

$\mathrm{d}$ to remain in the territory of a member state after having been employed in that State, subject to conditions which shall be embodied in implementing regulations to be drawn up by the Commission.

4 The provisions of this Article shall not apply to employment in the public service.

The passing of secondary legislation has served to implement Article 39. For instance Directive 68/360 ensures rights of entry and residence. Regulation 1612/68 regulates access to and conditions of employment. Regulation 1251/70 establishes the right to remain in the territory of a member state after employment there. Directive 64/221 establishes the rights of member states in connection with the derogations outlined in Article 39(3).

Article 39 is directly applicable. ${ }^{7}$ Furthermore, in Walrave and Koch and more recently Bosman, the ECJ established that Article 39 is capable of having horizontal as well as vertical direct effect. In Walrave the ECJ held that the 'prohibition of such discrimination does not only apply to the action of public authorities but extends likewise to rules of any other nature aimed at regulating in a collective manner gainful employment and the provision of services'. ${ }^{8}$ Also in Walrave the ECJ held that Article 39 would apply to work situations carried out outside the EU if the legal relationship of employment was entered into within the EU. Similarly, the reverse applies to instances whereby the legal relationship was formed outside the EU but the effect of the measure is felt within it. The prohibition on direct discrimination based on nationality extends to indirect discrimination in circumstances in which nationality neutral measures act as restrictions to free movement. ${ }^{9}$

Article 39 and subsequent secondary legislation establishes the rights of workers. The Treaty itself does not attempt a definition of a worker, although the ECJ has employed the word widely. In Lawrie-Blum the ECJ defined a worker as someone who performs services for and under the direction of another in return for remuneration during a certain period of time. ${ }^{10}$ In Walrave the ECJ held that the work must constitute an economic activity within the meaning of Article 2 of the Treaty. ${ }^{11}$ The ECJ regards most forms of non-trivial work as genuine work.

\section{The right of establishment}

Article 43 provides for:

Within the framework of the provisions set out below, restrictions on the freedom of establishment of nationals of a member state in the territory of another member state shall be prohibited. Such prohibition shall also apply to 
restrictions on the setting-up of agencies, branches or subsidiaries by nationals of any member state established in the territory of any member state.

Freedom of establishment shall include the right to take up and pursue activities as self-employed persons and to set up and manage undertakings, in particular companies or firms within the meaning of the second paragraph of Article 48, under the conditions laid down for its own nationals by the law of the country where such establishment is effected, subject to the provisions of the Chapter relating to capital.

The right of establishment refers to the right of individuals and firms to establish a business in a member state other than their own. Article 43 is directly applicable and directly effective. ${ }^{12}$

\section{Freedom to provide services}

Article 49 provides for:

Within the framework of the provisions set out below, restrictions on freedom to provide services within the Community shall be prohibited in respect of nationals of member states who are established in a State of the Community other than that of the person for whom the services are intended.

The Council may, acting by a qualified majority on a proposal from the Commission, extend the provisions of the Chapter to nationals of a third country who provide services and who are established within the Community.

The term 'service' is defined in Article 50(1) as being 'normally provided for remuneration, insofar as they are not governed by the provisions relating to freedom of movement for goods, capital and persons'. Such services include industrial and commercial services and the activities of craftsmen and professionals, excluding transport, insurance and banking for which alternative Treaty provisions exist. The right to provide services is afforded to individuals and firms. The right of establishment and the right to provide services is limited by the public policy, public security and public health limitation contained in Directive 64/221.

\section{The Walrave, Donà and Heylens cases}

As the EU is not an omni-competent organisation, it must be established that sport falls within the scope of the above Treaty Articles. The case law of the ECJ has established that Articles 39, 43 and 49 apply to sport. The Commission has also established that Article 81 and 82 dealing with competition law also apply (considered in Chapter 5).

Walrave $v$. Union Cycliste International 1974

Bruno Walrave and Noppie Koch were two Dutch professional pacemakers in motor-paced cycle races. Participants in these races ride pedal powered cycles. Each participant has a pacemaker on a motorcycle whom he follows. The pacemakers, who wear special clothing, aim to create a moving vacuum 
for the cyclist (stayer) to ride in. This enables the stayer to achieve speeds in excess of what a 'normal' cyclist could achieve. This can be as much as 100 kilometres per hour. The role of the pacemaker is therefore central to the sport, unlike the role of pacemakers in many other sports such as athletics. The pacemaker enters into a contract with the stayer, a cycling association or a sponsor. Until 1973, the pacemaker did not have to be of the same nationality to that of the stayer.

In November 1970, the Union Cycliste International (UCI, the international association for cycling sport) reviewed its rules on the conduct of motor-paced races for the forthcoming medium distance world cycling championships. From 1973, the pacemaker and the stayer had to be of the same nationality. UCI justified this action on the grounds that World Championships are intended to be competitions between national teams. Believing there to be a paucity of good Dutch stayers, $\mathrm{Mr}$ Walrave and $\mathrm{Mr}$ Koch acted as pacemakers for non-Dutch stayers, including Belgians and Germans. Faced with a restriction on their livelihood, they regarded this rule change as being discriminatory and a breach of EU law. Having failed to secure the repeal of the rule change, the two pacemakers initiated proceedings against the UCI, the Dutch cycling association and, because the championships were to be held in Spain, also the Spanish cycling association. ${ }^{13}$ Walrave and Koch wanted the rule to be repealed and wanted an injunction requiring the UCI to allow the pacemakers to take part in forthcoming events. The case was brought before the Arrondissementsrechtbank (District Court) in Utrecht in 1973 and referred to the ECJ using the reference procedures outlined in Article 234 of the Treaty. In answering the questions posed by the referring court, the ECJ came to the following conclusions.

First, the District Court asked the ECJ to rule on the compatibility of UCI's rule with Articles 12, 39 and 49 of the Treaty and Regulation No. 1612/68 of the Council of 15 October 1968 on the freedom of movement for workers within the Community. The ECJ initially had to establish whether EU law was applicable to sport. Paragraph 4 of the ruling established that, 'having regard to the objectives of the Community, the practice of sport is subject to Community law only in so far as it constitutes an economic activity within the meaning of Article 2 of the Treaty'.

Second, flowing from this general principle, the ECJ held that when the purpose of this 'economic activity' is to gain employment or remunerated service, it comes within the scope of Articles 39 to 42 or 49 to 55 of the Treaty, depending on the individual circumstances of the case. ${ }^{14}$ These Articles give effect to the general rule of Article 12 prohibiting discrimination on nationality. No distinction was therefore made between sport as an economic activity and other forms of work or services. Only when the practice of sport is of 'purely sporting interest', did the ECJ make such a distinction. As such national teams can discriminate on the grounds of nationality. ${ }^{15}$ 
Third, the prohibition of discrimination applies not only to the actions of public authorities but also to rules of any other nature aimed at collectively regulating gainful employment and services. ${ }^{16}$ Articles 39 and 49 therefore carry horizontal direct effect.

Fourth, relating to the applicability of EU law to events of world-wide significance, such as the cycling championships in question, the ECJ ruled that the rule on non-discrimination applies to all legal relationships in so far as these relationships, by reason either of the place where they are entered into or the place where they take effect, can be located within the territory of the EU. ${ }^{17}$

In accordance within the division between interpretation and application, the ECJ referred its answers back to the national court leaving it to determine whether EU law applied to the case and whether the pacemaker and the stayer were a team. In the event, Walrave and Koch declined to press for a judgment by the Arrondissementsrechtbank because the UCI had allegedly threatened to withdraw paced cycle racing from the World Championships (Weatherill 1989).

\section{Donà $v$. Mantero $1976^{18}$}

The second occasion on which the ECJ dealt with a sports-related case concerned nationality rules in Italian football. The Italian Football Federation, the Federazione Italiana del Gioco del Calcio (FIGC) controls the game of football in Italy. Under its rules, players are required to hold a federation membership card. Only the FIGC can issue such a card. Article 28 (g) of the federation's rules stated that normally only players of Italian nationality, residing in Italy could be issued with the card. An exemption was made for foreign nationals who have never been members of a foreign federation who are resident in Italy and ask to be enrolled as youths, amateurs or for recreational purposes. For all other players the FIGC had total discretion as to whether a card was to be issued. ${ }^{19}$ The rules effectively placed a heavy restriction on non-Italian footballers playing professional football in Italy. A challenge to these rules was brought by an agent who had attempted to recruit players from abroad. The agent had been hired by the chairman of an Italian league football club who wanted to explore the possibilities of bringing foreign players to the club. The agent, Gaetano Donà placed an advert in a Belgian sports newspaper. When, however, he claimed the costs of this advert back on expenses, he was refused on the grounds that he had acted too soon and Italian league rules prevented the use of foreign players. Mr Donà sued for the amount of the advert before the Giudice Conciliatore di Rovigo.

The Giudice Coniliatore di Rovigo referred the case to the ECJ. In particular, the national court asked the ECJ to establish if the nationality requirement for playing in professional football matches in Italy was compatible with EU law. The national court asked for clarification, initially on two key 
questions. First, whether Articles 12, 39 and 49 of the Treaty confer upon all nationals of the member states of the EU the right to provide a service anywhere in the EU and, secondly, whether football players also enjoy the same right where their services are in the nature of a gainful occupation. Depending on the answers to these two questions, a further two were asked. First, the national court asked the ECJ to rule whether this right may also be relied on to prevent the application of contrary rules drawn up by a sporting federation that regulates football on the territory of a member state. Second, the national court asked the ECJ whether the right in question is directly effective. On first sight, these four questions appear disproportionate for the purposes of the case. Some commentators have suggested the case was contrived for the purposes of opening the Italian football league to foreign players (Blanpain and Inston 1996).

Previously in Walrave the ECJ had established that sport is subject to EU law when it is practised as an economic activity and has the character of gainful employment or remunerated service. In particular, Articles 39 to 42 or 49 to 55 are applicable in this connection. These provisions give effect to Article 12 of the Treaty, prohibiting discrimination on the grounds of nationality.

Trabucchi, the Advocate General appointed to the case, appeared to suggest in his opinion delivered on 6 July 1976 that restrictions on nationality in football matches may be justified. He argued:

there is, in my view, nothing to prevent considerations of purely sporting interest from justifying the imposition of some restriction on the signing of foreign players or at least on their participation in official championship matches so as to ensure that the winning team will be representative of the state of which it is the champion team. A condition of this kind seems all the more reasonable when it is borne in mind that the team which wins the national championship is often chosen to represent its own state in international competitions.

Trabucchi was therefore of the opinion that even the rules of sporting organisations run as an economic concern may be exempt from the application of non-discriminatory Treaty provisions. Sport may be a business, but it may still also be simultaneously practised as an activity of purely sporting interest. The question is whether these restrictions are appropriate and proportionate to the end pursued. In answer to the referred questions, the ECJ partly confirmed the main thrust of Trabucchi's argument. The ECJ held:

1 Rules or a national practice, even adopted by a sporting organisation, which limit the right to take part in football matches as professional or semiprofessional players solely to the nationals of the State in question, are incompatible with Article 12 (ex 7) and, as the case may be, with Articles 39 to 42 or 49 to 55 (ex 48 to 51 or 59 to 66 ) of the Treaty, unless such rules or practice exclude foreign players from participation in certain matches for reasons which are not of an economic nature, which relate to the particular nature and context of such matches and are thus of sporting interest only. 
2 Article 39 (ex 48) on the one hand and the first paragraph of Article 49 (ex 59) and the third paragraph of Article 50 (ex 60) of the Treaty on the other - the last two provisions at least in so far as they seek to abolish discrimination against a person providing a service by reason of his nationality or the fact that he resides in a member state other than in which the service is to be provided - have direct effect in the legal orders of the member states and confer on individuals rights which national Courts must protect.

Once again, the ECJ referred its answers back to the national court for application.

UNECTEF $v$. Heylens $1987^{20}$

Although players are the most important feature of the sporting contest, many other individuals are involved in its production. In this connection, sports clubs also employ physiotherapists, coaches, dieticians, psychologists and trainers. Member states impose restrictions on foreign nationals wishing to take up such posts. For example, the individual in question is normally expected to be suitably qualified. In instances whereby qualifications are not awarded by bodies within the member state, member states are under a EU obligation to recognise equivalent qualifications gained in other member states. For some professions the EU has established specific mutual recognition standards. However, in many instances no such standards exist. Member states must therefore take appropriate measures to assess an individual's suitability. This is achieved by comparing the candidate's credentials with those required by national rules. The exercise of this judgement has however been called into question.

The Heylens case concerned a French requirement that in order to be a football trainer in France, a person must be the holder of a French footballtrainer's diploma or a foreign diploma which has been recognised as equivalent by the French government. George Heylens, a Belgian national, trained the Lille Olympic Sporting Clubs football team, a French club. His application for recognition of a Belgian diploma was rejected by the French Ministry of Sport. In the statement of reasons, the Ministry referred to the negative opinion of a special committee. However, the special committee gave no reasons for their negative opinion. The French football-trainers' trade union (UNECTEF) prosecuted Heylens and the directors of the football club before the Lille Criminal Court because of his continued employment with the club. The question of the compatibility with EU law of the French system for deciding on the equivalence of diplomas law was referred to the ECJ.

The ECJ referred to the fundamental right of workers to move freely within the EU. In this connection, the ECJ reiterated that member states must take all appropriate measures to ensure the fulfilment of the obligations arising from the Treaty. Nevertheless, the ECJ held that in the absence of harmonisation of conditions of access to a particular occupation, the member states are entitled to lay down the knowledge and qualifications needed in 
order to pursue it and to require the production of a diploma certifying that the holder has the relevant attributes. ${ }^{21}$ However, the ECJ held that a decision refusing to recognise the equivalence of a diploma must be reviewable to see whether it is compatible with Article 39 and to allow the person concerned to ascertain the reasons for the decision.

\section{Comment on Walrave, Donà and Heylens}

Combining the answers provided by the ECJ in Walrave, Donà and Heylens, it is possible to draw a number of conclusions relevant to the question of the pre-Bosman relationship between sport and EU law:

1 The ECJ has clearly established that sport is subject to EU law in so far as it constitutes an economic activity within the meaning of Article 2 of the Treaty. Exemptions from the principle of non-discrimination are permitted but linked with the practise of sport on a non-economic basis. As such, Article 39 does not concern itself with the composition of national teams.

2 Footballers are considered to be workers (employees of clubs) and as such are protected by Article 39. The broad definition of a worker adopted by the ECJ means that not only professional but also semi-professional and amateur players are included if they provide services in return for remuneration. Players who are not remunerated by the club but are financially rewarded indirectly (for instance through sponsorship) are not considered workers. Solo players who are not employed and remunerated by a club are also not considered workers in the context of Article 39 (but see below).

3 Article 39 is not only vertically directly effective, it is also horizontally directly effective. As such, Article 39 covers the activities of private sports associations.

4 Articles 43 and 49 dealing with establishment rights and freedom to provide services also apply to sport. Sportsmen and women who provide services but are not employed by clubs are afforded protection from discrimination by these Articles. As with Article 39, the discriminatory rule in question must be economic in nature and not of purely sporting interest. Two cases in English law illustrate this. In Wilander v. Tobin the Court of Appeal indicated, without deciding, that the sanction of suspending players who failed drug tests in tennis falls outside the scope of Article 49 as it concerned a rule governing sporting conduct. ${ }^{22}$ The players in question argued that the rule prevented them from supplying services within the EU. Similarly in Edwards v. BAF and IAAF, no breach of Article 49 was found concerning the International Amateur Athletics Federation's doping rules. ${ }^{23}$ These rules were also considered to be essentially concerned with sporting conduct and as such fell outside the scope of Article 49. However, as Lord Woolf argued in Wilander, EU law still has the 
potential to apply to the rules concerning the conduct of sport as well as to rules affecting the economic activity of sport.

5 Sports associations are entitled to lay down the knowledge and qualifications needed to take up employment but they must provide reason why they refuse to recognise a foreign diploma as equivalent. Furthermore, such decisions must be reviewable to establish compatibility with Article 39.

\section{URBSFA and others v. Bosman ${ }^{24}$}

Despite the growing body of case law relating to discriminatory practices in sport, the European Commission appeared unwilling to fully enforce the Walrave and Donà rulings. Consultations between the Commission (Internal Market DG) and UEFA on the continued use of nationality restrictions in European football continued unsuccessfully until the Bosman judgement. In 1978, an agreement between Commissioner Davignon and UEFA was concluded by which the federations had to modify their internal rules in order to abolish discrimination on the grounds of nationality. A temporary agreement was reached permitting first and second division clubs to restrict nonnationals to two per match. Despite objections from the Commission and the European Parliament, the restrictions remained in place. In December 1984, the Commission once again requested that discriminatory rules be amended to conform to EU law, this time by 1 July 1985. The response of UEFA and the national football associations was piecemeal. At the conference of the national Football Associations of EU member states held in July 1985, the associations approved a four-point plan proposed by UEFA.

1 Maximum of two non-nationals to be fielded per match.

2 'Sporting' nationality to be granted after five years' uninterrupted activity for a single association.

3 Qualifying period for applications for 'sporting' nationality to commence 1 July 1984.

4 Re-examination of the problem in 1989 to analyse the results obtained.

In September 1985, Commissioner Sutherland signalled his dissatisfaction with the agreement. Not only had UEFA failed to abide by the July deadline, but fundamentally UEFA's plans still contravened EU law. It was Sutherland's view that, 'players have their rights under Community law ... if a player has the chance to secure his own future during a relatively short career then who are the Commission to stop him? We are trying to ensure that there is no restriction on freedom' (Grayson 1994: 274).

Accordingly, the Commission once again requested that discriminatory practises in sport be abolished. At a further meeting between the Commission and UEFA/national federations in June 1987 the Commission proposed: 
1 The participation of three nationals from another member state in all official matches during the 1988-89 and 1989-90 seasons.

2 Continuous progress towards the achievement of total freedom of movement, to be completed by 1992 .

3 The creation of an evaluation group to consider the problems surrounding the free movement of professional players and its impact on professional football in general.

The proposals proved unacceptable to UEFA, although in 1991, after further consultations between the two parties, UEFA adopted the $3+2$ rule. From July 1992, clubs could play not more than three non-nationals in the team and two 'assimilated' players who have played in the country in question for five years uninterruptedly, including three years in junior teams. Initially, this rule applied to top division sides and was to be extended in the 1996/1997 season to all other non-amateur league's. Individual associations could frame rules allowing more foreign players to play. However, the $3+2$ rule applied universally in club matches organised by UEFA. The Bosman ruling brought an abrupt end to the $3+2$ formula.

The Commission's attitude towards discriminatory practises in sport throughout this period was somewhat contradictory. The Commission adopted a generally consistent view that discriminatory practises in sport should be abolished. However, they failed to ensure compliance with EU law and instead favoured a negotiated settlement with UEFA in the form of a gentleman's agreement. How can this be accounted for? First, the Commission recognised that, although sport could be defined as an economic activity, it still possessed certain qualities necessitating a softer interpretation of the law. Despite previous ECJ cases, European football in the late 1970s and early 1980s was regarded as a marginal economic activity at best. Second, the Commission appeared reluctant to use the direct sanction of competition law against UEFA. The status of the Competition Policy Directorate in the 1970s and early 1980s was not as established as it is today (see next chapter). Furthermore, the question of the relationship between sport and competition law was nascent. However, by 'sanctioning' the $3+2$ nationality rule, the Commission was effectively sanctioning discriminatory practises.

\section{Background}

On 10 May 1988, Jean Marc Bosman, a Belgian national, signed a two-year contract with the Belgian first division football club, SA Royal Club Liégeois (RC Liège). His contract with the club guaranteed him a gross basic salary, excluding bonuses of 75,000 Belgian Francs (BFR) a month, up until its expiration on 30 June $1990 .{ }^{25}$ Under Article 5 of his contract with the club, it was agreed that on expiry, either naturally or prematurely, the football club would retain the player's registration. Any future transfer of the player at the 
end of his contract would then be regulated by the rules of the Belgian Football Association.

In April 1990, two months before the end of the Bosman's contract, RC Liège offered the player a new one-year contract at BFR 30,000, the Belgian leagues (URBSFA) minimum wage. ${ }^{26}$ Bosman rejected the new terms as it represented a significant pay cut. In accordance with Article 46 of the Associations rules on transfers of professional and non-amateur players on expiry of their contracts, the club placed him on the transfer list as a 'compulsory transfer' at a price of BFR $11,734,000$, a price fixed by a calculation made on his last wage and the minimum in the event of him being transferred without the agreement of RC Liège. This means that if the player and the acquiring club agree to the transfer and the transfer fee set by the association's rules is paid, the transfer can go ahead even without the agreement of the vendor (the 'compulsory' transfer).

No club showed an interest in signing Bosman on a 'compulsory' transfer. On 1 June, the 'compulsory' element of the transfer came to an end and the period of 'free' transfer started. In this period a transfer fee can be freely negotiated as long as all three parties, including the vendor agrees. Bosman attempted to set up his own exit from the club by contacting an interested second division French league side, SA d'Économie Mixte Sportive de L'Union Sportive du Littoral de Dunkerque (US Dunkerque) who were prepared to offer the player BFR 90,000 a month. On the 27 July 1990, US Dunkerque and RC Liège agreed on the terms of the player's temporary transfer. The player was to move to US Dunkerque for one season in return for a payment of BFR 1,200,000, payable on receipt of the transfer certificate from URBSFA. US Dunkerque were given an option to purchase the player on a permanent basis at the end of the initial period for a further fee of BFR 4,800,000. The contracts between Bosman and US Dunkerque and US Dunkerque and RC Liège were conditional on the Belgian Association issuing a transfer certificate that was to reach the French Football Federation by 2 August.

Concerned about the solvency of Dunkerque, RC Liège did not seek the necessary international certificate from the Belgian Association. The transfer collapsed and under Article 46(5)(a) of the Belgian Association rules, RC Liège secured his suspension from the Belgian Football Authority on 31 July 1990. In its letter to the Association and to the player, the club explained, 'since no Belgian or foreign club has wished to transfer you and you have refused to sign that contract we find ourselves obliged to suspend you' (cited in Blanpain and Inston 1996: 62).

Unable to play professional football, Bosman applied to the Tribunal de Première in Liège on 8 August 1990. In addition to his main claim, Bosman applied for an interim order guaranteeing him three things. First, he wanted RC Liège and URBSFA to pay him BFR 100,000 a month whilst he found alternative employment. Second, to facilitate his search for alternative employment, Bosman wanted an order restraining RC Liège and URBSFA 
from claiming or levying any sum when appropriate work was found. Third, he wanted the case to be referred to the ECJ for a preliminary ruling.

On 9 November 1990, the Tribunal de Première ordered RC Liège to pay Bosman BFR 30,000 a month, granted the restraining order and referred the case to the ECJ seeking a preliminary ruling on the compatibility of the transfer system with Articles 6 and 39 of the Treaty. On 28 May 1991, on appeal, the Cour d'Appel in Liège quashed the Tribunal de Première's ruling relating to the preliminary reference to the ECJ. The first two orders relating to a monthly salary and a free transfer were however upheld. In June 1991, in response to this case, the ECJ withdrew Case-340/90 from its register.

Having been granted a free transfer, Bosman joined a French second division club, Saint-Quentin in October 1990. At the end of the season, that contract was terminated. In February 1992, Bosman signed for Saint-Denis de la Réunion, a contract also terminated after a short period. In May 1993, he then signed for a third division Belgian team, Royal Olympic Club de Charleroi. Suspicion grew that Bosman had been blacklisted by most European clubs.

In the main proceedings in August 1990, also brought before the Tribunal de Première, Bosman claimed damages against RC Liège. This related not only to breach of contract but also to the legality of the transfer system. In August 1991, Bosman brought action against UEFA as well attempting to have UEFA's transfer rules declared null and void and in breach of Articles 39, 81 and 82 of the EU Treaty. In April 1992, Bosman amended his claim against RC Liège and UEFA and brought a separate action against URBSFA. In these further applications, Bosman sought further compensation and attempted to reactivate the preliminary reference to the ECJ.

On 11 June 1992, the Tribunal de Première Instance ruled that RC Liège had acted unlawfully in causing Bosman's transfer to US Dunkerque to collapse. For this, Bosman was to be compensated. In addition, the national court made a reference to the ECJ for a preliminary ruling on the interpretation of Articles 39, 81 and 82 of the Treaty in relation to the operation of the transfer system. A further appeal was held before the Cour d'Appel in Liège in October 1993. The findings of the Tribunal de Première Instance were upheld and the Cour d'Appel made its own reference to the ECJ. Acting on a suggestion from Bosman, the national court also requested an examination of the rules relating to restrictions on foreign players. The Cour d'Appel submitted the following questions to the ECJ:

Are Articles 39, 81 and 82 of the Treaty of Rome of March 1957 to be interpreted as: (1) prohibiting a football club from requiring and receiving payment of a sum of money upon the engagement of one of its players who has come to the end of his contract by a new employing club; and (2) prohibiting the national and international sporting associations or federations from including in their respective regulations provisions restricting access of foreign players from the European Community to the competitions which they organise? 
These two questions relate to two UEFA sanctioned practices regarding transfer fees and restrictions on foreign players. First, under the UEFA international transfer rules, a club selling a player is entitled to compensation for training and development from the acquiring club, even if the player was no longer under contract with the vendor. Only the first club is entitled to compensation for training whereas each subsequent club is only entitled to a development fee. If the club's valuation of the player differs, a board of experts established by UEFA fixes the fee having taken into account the gross income of the player in the preceding season multiplied by a factor depending upon the player's age.

The second question related to the widely employed practise in European football of restricting the number of foreign players able to play for a club. After protracted consultations between the European Commission and UEFA, the $3+2$ rule was adopted (see above). The ECJ handed down its full judgement on 15 December 1995. By doing so, the ECJ supplied the definitive answers to the questions posed by the national court.

\section{Transfer rules}

In relation to the application of Article 39 concerning transfer rules, the ECJ did not significantly diverge from the opinion of Advocate General Lenz. The ECJ dismissed the claims of URBSFA, UEFA and some national governments that Article 39 was not applicable. URBSFA had claimed that only the major clubs are economic units and that rules on transfers relate only to the relationship between clubs. UEFA had claimed that EU authorities have always respected the autonomy of sport and to change the transfer system would fundamentally affect the whole organisation of sport. ${ }^{27}$ The German government had claimed that football is not an economic activity at all and sport should be seen in the same light as culture. In addition, the German government, referring to freedom of association and subsidiarity, argued that the $\mathrm{EU}$ must limit their involvement in this area to what is strictly necessary. ${ }^{28}$

The ECJ repeated the findings of the Advocate General in relation to the definition of sport as an economic activity. ${ }^{29}$ Furthermore, the ECJ agreed with Advocate General Lenz in relation to the issue of transfer rules only concerning the relationship between clubs and not the relationship between club and player. If a player's employment opportunities are restricted by this relationship between clubs, then Article 39 is relevant. ${ }^{30}$ In relation to UEFA's claim that an adverse ruling would have huge consequences for the organisation of football, the ECJ held that the consequences of a judgement cannot be allowed to interfere with the principle of law, nor its application. ${ }^{31}$ On the question of the cultural analogy, the ECJ argued that this cannot be accepted because the original reference from the national court did not relate to the conditions under which EU powers of limited extent may be exercised but on the scope of the freedom of movement of workers guaranteed by Article $39 .{ }^{32}$ Regarding the issue of freedom of association, the ECJ held that 
the rules laid down by sporting associations cannot be seen as necessary to ensure enjoyment of that freedom by those associations, by the clubs or players. ${ }^{33}$ Finally, in relation to the claim that the principle of subsidiarity applies, the ECJ held that this principle cannot be used to restrict the exercise of rights conferred on individuals by the Treaty. ${ }^{34}$ On the question as to whether the dispute between Bosman and URBSFA was wholly internal, the ECJ ruled that, although case law had established that Article 39 cannot be applied to situations that are wholly internal to member state, the cross border requirement had been in evidence as Bosman was seeking to move abroad. $^{35}$

Accordingly, the ECJ held that Article 39 does apply to the rules laid down by URBSFA, FIFA or UEFA, thus confirming the horizontal direct effectiveness of Article 39. Having established this fact, the ECJ proceeded to assess the extent to which transfer rules form an obstacle to freedom of movement for workers. In this connection the ECJ agreed with Bosman and the Advocate General that these rules did constitute such an obstacle. ${ }^{36}$ This point is not affected by the fact that UEFA's 1990 transfer rules state that the business relationship between the two clubs is to exert no influence on the activity of the player, who is free to play for his new club. Despite this reference, the purchasing club must still pay a fee to the vendor. As such the vendor maintains a financial interest in the player, even though they hold no contractual interest in him. This is an obstacle to the freedom of movement of workers. Furthermore, the fact that these rules are equally applied is irrelevant.

The ECJ held that the 'public interest' justification for the maintenance of the transfer system claimed by the defendants should also be dismissed. URBSFA, UEFA and the governments of France and Italy had claimed that transfer rules are justified by the need to maintain a financial and competitive balance between clubs and to support the search for talent and the training of young players. ${ }^{37}$ In this connection, the ECJ agreed with the Advocate General that this aim was legitimate but less-restrictive measures could achieve the same aims as the transfer system. ${ }^{38}$

In answer to the first question posed by the national court, the ECJ therefore clearly answered that Article 39 precludes the application of transfer rules which permits payment for an out-of-contract player wishing to move between clubs in different member states.

\section{Nationality restrictions}

The ECJ drew the same conclusion in relation to the application of Article 39 to rules restricting the number of foreign players eligible to play for clubs. The ECJ held that Article 39(2) guarantees freedom of movement for workers and the abolition of any discrimination based on nationality. Nationality quotas clearly represent a breach of these provisions even though the rules relate to the fielding of players and not to their employment. ${ }^{39}$ It is after all unlikely, 
although not unheard of, for clubs to employ players they are incapable of fielding. Having established the existence of an obstacle to free movement, the ECJ reviewed the arguments presented by UEFA, URBSFA and some national governments justifying such restrictions on the grounds that they were non-economic sporting rules. The ECJ rejected this justification in accordance with the Opinion of the Advocate General. First, on the question that nationality restrictions maintain the link between club and country, the ECJ held that no rule has been established linking a club to a locality, therefore none should exist linking a club to a country. Second, on the issue relating to nationality restrictions being necessary to ensure a pool of players eligible to play for the national team, the ECJ argued that no rules exist limiting a national team's choice of players to one association. National teams can still pick eligible players who play abroad. Third, the ECJ held that nationality restrictions do not maintain a competitive balance between clubs because the richer teams can still recruit the best national players regardless. Finally, in relation to UEFA's argument that nationality restrictions were sanctioned by the European Commission, the ECJ held that the Commission does not possess the power to authorise practices that are contrary to the Treaty. ${ }^{40}$

To the second question posed by the national court, the ECJ therefore once again held that Article 39 had been breached, this time in relation to the use of nationality restrictions. In relation to the application of Articles 81 and 82 (ex 85 and 86), the ECJ simply remarked, 'since both types of rule to which the national Court's questions refer are contrary to Article 48 (now 39), it is not necessary to rule on the interpretation of Articles 85 and 86 of the Treaty' ${ }^{41}$ On the grounds mentioned above, the ECJ answered the questions posed by the Cour d'Appel, Liège in the following way:

1 Article 48 of the EEC Treaty precludes the application of rules laid down by sporting associations, under which a professional footballer who is a national of one member state may not, on the expiry of his contract with a club, be employed by a club of another member state unless the latter club has paid the former club a transfer, training or development fee.

2 Article 48 of the EEC Treaty precludes the application of rules laid down by sporting associations under which, in matches in competitions which they organise, football clubs may field only a limited number of professional players who are nationals of other member states.

3 The direct effect of Article 48 of the EEC Treaty cannot be relied upon in support of claims relating to a fee in respect of transfer, training or development which has already been paid on, or is still payable under an obligation which arose before the date of this judgement, except by those who have brought proceedings or raised an equivalent claim under the applicable national law before that date.

The imposition of the temporal limitation on the judgement concerning the transfer system avoided the inevitable chaos a retroactive ruling on 
transfers would have created. Nevertheless, the impact of Bosman on sport had immediate effects (see for instance Morris et al. 1996, Miller 1996, Gardiner et al. 1998, Beloff et al. 1999 and Caiger and Gardiner 2000).

First, clearly the international transfer system and nationality rules had to be re-modelled. Nevertheless, the ruling does not directly affect transfers when a player is in contract. The ruling only affects players who are out of contract.

Second, internal transfer rules remain only theoretically untouched by Bosman because the ECJ decided to base the ruling on Article 39, not Article 81 relating to restrictive agreements. Article 39 applies only to the international transfer system and not to situations that are wholly internal. As such, national transfer rules continue to apply to cases where a player moves between two clubs in the same association. However, following Bosman, the Commission held the opinion that certain aspects of national transfer systems violate Article 81. Although the indirect consequence of the ruling saw most internal transfer rules being reformulated in Europe, the Commission continued their investigation into such rules leading to the total reformulation of transfer rules in 2001 (see next chapter).

Third, the ruling does not affect transfers of non-EU nationals from one EU/EEA state to another. Furthermore, the ruling does not concern transfers from the EU to third countries. However, although non-EU/EEA players cannot rely on the ruling in relation to transfers, players who are nationals of a country that has concluded an association or co-operation agreement with the EU prohibiting discrimination on the grounds of nationality cannot be excluded from playing in a team because of their nationality. This also assumes that the free movement provisions have direct effect. Such countries include Morocco, Tunisia, Algeria, Turkey, Poland, Slovakia, the Czech Republic, Bulgaria and Romania. Norway, Iceland and Liechtenstein are part of the European Economic Area (EEA) and are thus fully covered by the ruling. As such the ruling fully applies to 18 European countries. ${ }^{42}$ The application of Article 81 may however alter the situation regarding the transfer of players from third countries. ${ }^{43}$

Fourth, the ruling does not affect the composition of national teams. This is because Article 39 relates only to economic activity and national teams are not deemed as such. ${ }^{44}$ Is this view still defensible? In modern international sport many sportsmen and women have entered into appearance contracts with their national associations (Hoskins 1999: 10-11). As Leeds United and Rio Ferdinand discovered, participation in the Football World Cup can have an enormous influence on a player's value. ${ }^{45}$

Fifth, the ruling was not restricted to football. Sport, in so far as it constitutes an economic activity, is subject to EU law. This means that all sports in Europe operating restrictions on EU citizens and similar transfer rules to football, must comply. The main sports to be affected are ice hockey, basketball, handball and rugby. Clearly not all sports are as commercially developed as football. 


\section{Comment on Bosman}

The ECJ first had to establish the applicability of Treaty rules to sports bodies. In this connection the ECJ did not break new ground by merely confirming the findings in Walrave and Donà which established that sport is subject to EU law in so far as it constitutes an economic activity. In addition the ECJ confirmed the horizontal direct effectiveness of Article 39. The reach of Article 39 (and for that matter 43 and 49) went beyond the acts of public authorities to cover the actions of private individuals and firms. Article 39 therefore covers any rules aimed at regulating employment in a collective manner. If Article 39 was not horizontally directly effective, private actors could effectively re-construct restrictions previously abolished between states.

The ECJ then needed to establish whether the rules on eligibility criteria and international transfer constituted restrictions. In this connection, the ECJ went beyond a mere confirmation of previous sports-related case law by suggesting that all restrictions to free movement (and not just discriminatory ones) are caught within the scope of Article 39.

Nationality rules The ECJ found that UEFA's $3+2$ nationality rules clearly placed foreign nationals at a disadvantage in comparison to home nationals. However, the ECJ held that nationality rules were not simply an example of discrimination, but were an obstacle to free movement as they restricted access to the employment market. This represents 'a significant change of emphasis' and one which potentially has far-reaching consequences for sport (O'Keefe and Osbourne 1996: 119). By taking this stance, the ECJ has established a much stronger link between sport and the EU. If nationality restrictions are not to be simply considered an issue of discrimination but rather an obstacle to free movement, then potentially a much greater range of sporting rules will be caught by the scope of Article 39. Therefore, rather than 'contracting' into the Treaty, sport must now justify why it should 'contract' out of it.

Transfer system On transfers, the ECJ held that the nature of the transfer rules imposed non-discriminatory restrictions on players, even though such rules govern business relations between clubs. The ECJ decided to view the transfer rules as a restriction despite the fact that the existence of the transfer rule did not make it more difficult for a player to move between clubs in different member states than between clubs in the same state. As such, the ECJ held that the application of Article 39 went beyond a mere prohibition of discrimination, but extended to all restrictions. This extension had first been made in Ramrath and in Kraus, two cases unconcerned with sport. ${ }^{46}$ However, Bosman differed from these cases because the restriction was not created in the host state but the home state, i.e. Bosman's own state of Belgium. Bosman's freedom of movement was restricted by the actions of 
parties within his own country, not the host country. Although previous cases prohibited restrictions being placed on an individual leaving a state (as opposed to entering) in relation to Article 43, this was the first occasion it was extended to Article 39. This broadening took place despite the ruling in $\mathrm{Keck}^{47}$ in which the ECJ held that Article 28 (free movement of goods) does not apply to rules on certain selling arrangements provided that they apply to all relevant traders within the national territory and that they affect in same manner, in law and in fact, the marketing of domestic and imported goods. A case can therefore be made to apply Keck to Bosman given that transfer rules applied equally to all clubs in all member states and affected foreign and domestic transfers equally. The ECJ chose not to extend Keck beyond the free movement of goods, instead relying on the Alpine Investments ruling. ${ }^{48}$ Alpine concerned restrictions within the host state affecting access to the market of another member state. Keck concerned the rules of the 'importing' state. The ECJ therefore made a distinction between the two cases equating Bosman with Alpine and not Keck (O'Keefe and Osbourne 1996: 116-118).

Having established that nationality rules and transfer rules constitute restrictions on mobility, the ECJ had to examine the question of justified restrictions and proportionality. At issue here was the sporting exception. Restrictions of a discriminatory nature can only be justified if covered by Article 39(3) relating to grounds of public policy, public security or public health. Non-discriminatory measures can only be justified by imperative reasons' such as the need to protect sports social function. However, as indicated above, these justifications do not take sport outside the scope of EU law. This is a significant finding and one which distinguishes Bosman from earlier sports-related case law. The ECJ indicated that sport possesses particular features that mark it out from other 'normal' industries. However, the justifications submitted to the ECJ in support of the maintenance of nationality rules and the transfer system were rejected, thus placing further limits on concept of a sporting exception. Such restrictions were not considered proportionate to the aims submitted. Basing their judgement on the opinion of the Advocate General, the ECJ argued that alternative measures such as collective wage agreements and financial redistribution between the clubs were more proportionate measures. Both mechanisms contain features that would arguably be considered illegal in 'normal' industries. Whilst, therefore, the ECJ's ruling represented a damning condemnation of traditional sporting practices, it is incorrect to assume that the Court treated sport in the same manner as any other industry. Arguably, therefore, the birth of EU sports law had its roots in Bosman. Nevertheless, Bosman had more to do with the Single Market project and the scope of Article 39 than it did sport. The sweeping condemnation of all out-of-contract payments rejected any notion of a reformed transfer system - a possibility raised by the Advocate General. ${ }^{49}$ 
Nevertheless, Bosman has far-reaching consequences for sport. Sport is clearly subject to EU law and Article 39 is horizontally directly effective. Furthermore, Article 39 extends beyond the prohibition of discriminatory practices to include non-discriminatory practices which restricts free movement. By adopting such an approach the argument is now less concerned with whether sport falls outside the Treaty but under what circumstances are sports rules justifiable under the Treaty. However, the key implication of Bosman related to enforcement. The full consequences of Walrave and Donà did not occur because the Commission did not rigorously enforce the rulings. Following Bosman the Commission became more energetic in enforcing the competition policy implications of the ruling. This has had a profound effect on how sport is being regulated in the twenty-first century.

\section{The Deliège and Lebtonen cases}

As indicated above, in Bosman the ECJ recognised 'the considerable social importance of sporting activities'. ${ }^{50}$ However, it went on to explain why nationality restrictions and the operation of the international transfer system could not be justified and as such exempted from the application of Article 39. Nevertheless, as Foster explains, 'in retrospect this paragraph can be seen as the genesis of the Court's attempt to formulate a policy of nonintervention in sport' (Foster 2000a: 47). The ECJ has recently been requested to consider two further sports-related disputes, one concerning judo, the other basketball.

Christelle Deliège $v$. Asbl Ligue Francophone de Judo and Others ${ }^{51}$ In Deliège, the ECJ heard a case concerning a Belgian judoka who claimed that her career had been impeded by the refusal of the Belgium judo authority to allow her to participate in the 1992 Olympic Games held in Barcelona and the 1996 Games held in Atlanta. In order to participate in these events potential participants needed the authorisation from the relevant national federation. Although considered a very good judoka, Miss Deliège failed to make the Belgian Olympic team, having failed to achieve the necessary qualification criteria. Failure to gain selection would undoubtedly inhibit her career. Miss Deliège believed that, although judo is considered an amateur pursuit, she was carrying out an economic activity and as such had economic rights guaranteed by Articles 49, 81 and 82 of the EC Treaty. The case was referred to the ECJ by the Tribunal de Première de Namur who asked:

Whether or not it is contrary to the Treaty of Rome, in particular Articles 49, 81 and 82 of the Treaty, to require professional or semi-professional athletes or persons aspiring to professional or semi-professional activity to be authorised by their federation in order to be able to compete in an international competition which does not involve national teams competing against each other. 
As in Bosman, the ECJ did not address the question of competition law. On the question of the freedom to provide services, the ECJ confirmed that the activities of athletes (even amateur athletes) are capable of falling within the scope of Article 49. Organising the sporting contest allows the organisers to commercially exploit the secondary features of the contest such as broadcasting and sponsorship rights. Furthermore, Deliège received a grant to train and compete. Despite giving clear guidance in this matter, the ECJ did not form an opinion on whether Miss Deliège's activities were economic in nature. This was for the national court to decide. The ECJ did however acknowledge the 'considerable social importance of sport' ${ }^{52}$ and did refer to the Amsterdam Treaty's Declaration on the social significance of sport. ${ }^{53}$ In this connection, the ECJ considered the selection rules derived from a need inherent in the organisation of the sport and as such were not to be considered a restriction on the ability to provide services. Allowing anyone to compete in competitions is clearly unworkable. However, the ECJ held that sports organisations must be able to demonstrate that selection rules are based on objective justifiable principles. On 11 April 2000, the ECJ delivered its judgement. It held:

A rule requiring professional or semi-professional athletes or persons aspiring to take part in a professional or semi-professional activity to have been authorised or selected by their federation in order to be able to participate in a highlevel international sports competition, which does not involve national teams competing against each other, does not in itself, as long as it derives from a need inherent in the organisation of such a competition, constitute a restriction on the freedom to provide services prohibited by Article 49 of the EC Treaty.

Lehtonen and Castors Canada Dry Namur-Braine $v$. Fédération Royale des Sociétés de Basketball and Ligue Belge-Belgische Liga ${ }^{54}$

The second case concerned transfer deadlines in Belgian Basketball. Jyri Lehtonen, a Finnish Basketball player was transferred from a Finnish to a Belgian basketball team. However, the Belgian basketball federation refused to register him on the grounds that the transfer had not taken place within the specified 'transfer window'. Un-registered players are prevented from competing in Belgian competitions. In Belgium, players are unable to be transferred outside these transfer seasons. This is a common practise in European sport. To make matters worse for Castors Braine, the Belgian team who had acquired Lehtonen, they had already played him in a winning game only to have the result over-turned due to the breach of transfer rules. Lehtonen and Castors Braine applied to the Court of First Instance in Brussels for an interim order on the over-turned match and the sanctions imposed on Lehtonen. The national court referred the following question to the ECJ: 
Are the rules of a sports federation which prohibit a club from playing a player in the competition for the first time if he has been engaged after a specified date contrary to the Treaty of Rome (in particular Articles 12, 39, 81 and 82) in the case of a professional player who is a national of a member state of the European Union, notwithstanding the sporting reasons put forward by the federations to justify those rules, namely the need to prevent distortion of the competitions?

In answering the above question, the ECJ was guided by Walrave, Donà and Bosman in deciding that the activities of sport are subject to EU law and that employees of sports clubs are to be considered workers. However, as in Deliège, the ECJ acknowledged the 'considerable social importance of sport' and made further mention of the Amsterdam Treaty's Declaration on the social significance of sport. ${ }^{55}$ On the question of whether the rules on transfer deadlines constituted a restriction on free movement, the ECJ found that the rule in question was such an obstacle even though the restriction related to fielding players and not employing them. The ECJ then had to decide whether such restrictions were justifiable and proportionate. Could the rule be justified as non-economic in nature and as such of sporting interest only? In the Opinion of the Advocate General, the protection of a sporting competition against distortion is in the public interest. As such public interest justifications could be employed to protect transfer deadlines. The ECJ agreed with the submissions of the Basketball Federation that rules on transfer deadlines were sporting rules which were necessary for the organisation of the game. Late transfers could substantially alter the sporting strength of teams in the course of the championship thus calling into question the proper functioning of sporting competition. However, the ECJ argued that such rules must not go beyond what is necessary for achieving the desired aim. The differential treatment of players from inside and outside Europe, which the rules promoted, went beyond what was necessary and as such were prohibited by Article 39.56 Again, the ECJ did not address the question of competition law. Therefore in answer to the questions referred by the Tribunal de Première Instance, Brussels, on 13 April 2000, the ECJ held:

Article 39 EC precludes the application of rules laid down in a member state by sporting associations which prohibit a basketball club from fielding players from other member states in matches in the national championship, where they have been transferred after a specified date, if that date is earlier than the date which applies to transfers of players from certain non member countries, unless objective reasons concerning only sport as such or relating to differences between the position of players from a federation in the European zone and that of players from a federation not in that zone justify such different treatment.

\section{Comment on Deliège and Lehtonen}

Deliège and Lehtonen bring a degree of respite for sport without undermining previous sports case law. As Bell and Turner-Kerr remark, 'at a time when 
it seems that the legality of nearly every sports regulation is being called into question, it is at least welcome for the ECJ to recognise that there are certain areas where sports governing bodies retain the authority and competence to regulate the disciplines for which they are responsible' (Bell and Turner-Kerr 2002: 260). In essence the rules which sports bodies retain competence over concern those which are inherent in the conduct and/or organisation of sporting events.

The significance of Deliège lies in the ECJ's view that selection criteria do not necessarily constitute a restriction under Article 49. This places a small limit on the application to sporting contexts of the freedom to provide services provisions. In Lehtonen, the significant finding is that, even though transfer windows do constitute a restriction to free movement, they are able to be justified on sporting grounds and as such are capable of being exempt from the application of Article 39..$^{57}$ The Opinion of the Advocate General who equated such sporting interest arguments not with sporting autonomy justifications but with the 'public interest' justification is potentially significant. If sports bodies are able to connect sporting interest arguments with public interest justifications, this could act as a vehicle for the protection of the remaining autonomy sports organisations possess. Given that the purpose of Articles 39 and 49 is to protect workers and not the organisation of sport, the public interest finding could prove a significant precedent for sports bodies, particularly given that the Commission are beginning to draw similar findings in connection with their sports-related competition law case load.

The Bosman ruling demonstrated that the ECJ was sensitive to the economic context surrounding the recently completed Single Market project. The Deliege and Lebtonen rulings also need placing in context. First, the rulings took place within the context of an on-going discussion in the EU on how best to reconcile the economic and socio-cultural dimensions of sport within the EU structure..$^{58}$ Significantly, in both cases the ECJ made mention of the Amsterdam Treaty's Declaration on Sport, even though it carries no legal force. The reference to the Declaration indicates that the ECJ has been sensitive to this debate. Although the ECJ has consistently refused to answer referred questions concerning competition law, the reference to the Declaration has undoubtedly informed the Commission's approach to sport.

Second, Bosman allowed the ECJ to clarify and extend some important issues relating to the scope of Article 39. The legal broadening that took place in Bosman was arguably as significant to the free movement of workers as the wide definition of restriction adopted in Dassonville was to the free movement of goods. ${ }^{59}$ As such, following Bosman, Lehtonen placed limits on the scope of Article 39 in a manner similar to Keck's limitation of Article 28 following Dassonville.

Nevertheless, as Foster argues, there are limits to the rulings. In Lehtonen, the ECJ made specific mention of the impact transfer deadlines have on playoff games. ${ }^{60}$ Does this justification extend to all-play-all leagues? Some 
sports prevent a player from competing for two separate sides in a knockout competition but allow this in a league format. As such, 'the general legality of transfer deadlines per se cannot safely be assumed by the judgment' (Foster 2000a: 49). Furthermore, in Deliège, it remains unclear exactly what objective standards for selection are. Objective criteria is apparent in sports such as tennis and golf where rankings and handicap determine competition entrance. However, subjective criteria is apparent in other team sports where picking players who 'blend' is more important than picking the best players. Deliege also avoided the question of selection for national teams. The ECJ held that it was affiliation to the appropriate national federation that was the basis for selection to international tournaments and not nationality (Foster 2000: 51). In a wider sense, the key limit to the rulings is that very little sport has been taken outside the scope of the Treaty. In fact, by finding that unpaid amateur sports men and women are workers, the rulings have effectively further undermined the concept of sport as a non-economic activity.

\section{Conclusions}

The value of an actor-centred institutional analysis is demonstrated when observing the impact of ECJ jurisprudence on the sports policy subsystem. An 'old' institutional analysis would tend to confirm the privileged position the Court enjoys in terms of interpreting and applying the law. A 'new' institutional analysis reveals the extent to which informal practices and complex institutional relationships have affected the development of EU sports law and policy.

The ECJ is clearly an important agenda setter in the EU in that it not only defines the content of the EU's systemic agenda, it also specifies the conditions under which an issue is transferred to the institutional agenda for active policy development. The role of the ECJ in this respect should not however be viewed as deterministic. The relationship between the ECJ and the other EU institutions is crucial for policy definition. Sufficient sports-related case law exists to illustrate this point. ECJ rulings in Walrave and Donà established sport as an item on the EU's systemic agenda. The rulings established that sport was subject to EU law whenever practiced as an economic activity. The rulings should be seen in the context of the time. The 1970s have been characterised as a period of stagnation for the EU. Economic and political crisis contributed to a slowing of 'ever-closer union'. In the absence of a political impetus, the ECJ ensured the original Treaty of Rome bargain was continued. Hence, Walrave and Donà served to widen the scope of the Treaty and afford greater protection to workers. The impact of the rulings on sport was however limited. The Commission did little to enforce the central findings in the cases, preferring instead a negotiated settlement with the sports authorities. As such, sport remained in a largely latent regulatory 
space and the transfer of sport from the EU's systemic to the institutional agenda remained incomplete.

The major impetus for sports eventual passage on to the institutional agenda for active EU consideration came with Bosman. Bosman destroyed the Commission's negotiated settlement approach. The changed economic status of sport contributed to the ECJ's forceful ruling and the Commission's more energetic use of competition law to enforce Bosman. Despite the submissions of various governments in Bosman, the ECJ's ruling was also a response to a political impetus. Although a legal and bureaucratic exercise of immense proportions, the newly completed Single Market represented a triumph of political will. The ECJ's extension of the scope of Article 39 was consistent with the broad thrust of the Single European Act/Single European Market project. As such, sports functional link to the Single Market was an unanticipated consequence of the wider Single Market project. Sport now operated within a EU regulatory environment. The legal consequence of Bosman was that the EU no longer had to justify why sport was subject to EU law, but rather sport would have to justify why it should be exempt from the Treaty. Even so, the acknowledgement by the ECJ that sport was different to other 'normal' industries may be interpreted as the genesis of EU sports law.

Items on the EU's systemic agenda are often transferred on to the institutional agenda with definitional bias. Sport, for instance, was transferred through a legal/regulatory venue involving a close relationship between the ECJ and the Commission. However, the EU's institutional agenda is very open. As an item for active policy consideration, sport has proved a relatively malleable item. The rulings in Deliège and Lebtonen again reflect the political context of the day. The ECJ has confirmed that sport is subject to EU law but has given clearer guidelines on sporting justification arguments. In this connection, the ECJ has been sensitive to the post-Bosman political debate on how to reconcile EU law with sports social status. Deliège and Lehtonen represent the ECJ's contribution to the construction of the separate territories approach and, therefore, the development of EU sports law. The member states, the European Parliament and the Education and Culture Directorate General have been active in promoting this message. Deliège and Lehtonen have also informed the activities of the Directorate General for Competition Policy. Whereas the ECJ has responded to the political debate by being sympathetic to the 'inherent sporting rule' justification when deciding cases, the Commission has recently indicated that exemptions from competition law may be an appropriate way of reconciling EU law with sports social status. It is to this that the next chapter turns.

\section{Notes}

1 Case 36/74, Walrave and Koch v. Association Union Cycliste Internationale [1974] ECR 1405. Case 13/76, Donà v. Mantero [1976] ECR 1333. Case 222/86, UNECTEF v. Heylens [1987] ECR 4097. 
2 Case C-415/93, Union Royale Belge Sociétés de Football Association and Others v. Bosman [1995] ECR I-4291.

3 Joined cases C-51/96 and C-191/97, Deliège v. Asbl Ligue Francophone de Judo and others [2000] ECR I-2549. Case C-176/96, Jyri Lehtonen and Castors Canada Dry Namur-Braine v. Fédération Royale des Sociétés de Basketball and Ligue Belge-Belgische Liga [2000] ECR I-2681.

4 Case 26/62, Van Gend en Loos v. Nederlandse Administratie der Belastingen [1963] ECR I. Case 6/64, Costa v. ENEL [1964] ECR 585.

5 See note 4.

6 Article 234.

7 Case 167/73, Commission v. French Republic [1974] ECR 359. Re: nationality restrictions in the French maritime sector.

8 Walrave, para 17.

9 Case 152/73, Sotgiu v. Deutsche Bundespost [1974] ECR 153. Re: the discriminatory granting of allowances to workers.

10 Case 66/85, Lawrie-Blum v. Land Baden-Württemberg [1986] ECR 2121.

11 Walrave, para. 4.

12 Case 2/74, Reyners v. Belgian State [1974] ECR 631. Re: refused admission to the Belgian bar on nationality grounds.

13 The Spanish cycling association was later dismissed from the suit. At the time, Spain was not a member of the EU.

14 Walrave, para. 5.

15 Walrave, para. 8.

16 Walrave, para. 17.

17 Walrave, para. 28.

18 Case 13/76, Donà v. Mantero [1976] ECR 1333.

19 Facts taken from Opinion of Advocate General Trabucchi, Delivered on 6 July 1976.

20 Case 222/86, UNECTEF v. Heylens [1987] ECR 4097.

21 Heylens, paras. 8-10.

22 Wilander v. Tobin [1997] EuLR 265.

23 Edwards v. British Athletics Federation and International Amateur Athletics Federation [1997] EuLR 721.

24 Case C-415/93, Union Royale Belge Sociétés de Football Association and Others v. Bosman [1995] ECR I-4291.

25 With bonuses and other payments, the players' average monthly earnings were in the region of BFR 120,000.

26 As specified in the statutes of ASBL Union Royale Belge des Sociétés de Football Association (URBSFA).

27 Bosman, para. 71.

28 Bosman, para. 72.

29 Bosman, para. 73.

30 Bosman, para. 75.

31 Bosman, para. 77.

32 Bosman, para. 78.

33 Bosman, para. 80.

34 Bosman, para. 81.

35 Bosman, paras. 88-91. 
36 Bosman, para. 104.

37 Bosman, para. 105.

38 Bosman, para. 110.

39 Bosman, para. 120.

40 Bosman, paras. 123-136.

41 Bosman, para. 138.

42 In case C-438/00, Deutscher Handballbund e. $v$. v. Maros Kolpak (pending), the Advocate General has formed the opinion that rules of a sports association restricting the participation of Slovak players in Championship and Cup matches of federal and regional leagues are contrary to Article 38 of the EU-Slovakia Agreement.

43 Note the opinion of the Advocate General in Case C-246/98, Tiborbalog v. Royal Charleroi Sporting, Opinion of 29 March 2001 (case subsequently withdrawn). See next chapter.

44 See Case 13/76, Donà v. Mantero [1976] ECR 1333.

45 Ferdinand joined Leeds from West Ham in November 2000 for $£ 18$ million. Following a series of good performances for England in the 2002 Japan/South Korea World Cup he joined Manchester United for $£ 30$ million in July 2002. Now let's never mention it again.

46 Case C-106/91, Ramrath v. Ministre de la Justice [1992] ECR I-3351; Case C19/92, Kraus v. Land Baden-Württemberg [1993] ECR I-1663.

47 Joined cases C-267 and 268/91, Keck and Mithouard [1993] ECR I-6097. Re: the prohibited practice under French law of reselling goods at a loss.

48 C-384/93, Alpine Investments B V v. Minister van Financiën [1995] ECR I-1141. Re: a Dutch ban on unsolicited telephoning of potential customers.

49 Opinion of the Advocate General, para. 239.

50 Bosman, para. 106.

51 Joined cases C-51/96 and C-191/97, Deliège v. Asbl Ligue Francophone de Judo and Others [2000] ECR I-2549.

52 Deliège, para. 41.

53 Deliège, para. 42.

54 Lehtonen.

55 Paras. 32 and 33 Lehtonen.

56 Players from a federation outside the European zone were subject to a transfer deadline of 31 March, whereas players inside the European zone were subject to a transfer deadline of February 28.

57 Lehtonen, para 51-55.

58 See Chapter 6.

59 Case 8/74, Procureur du Roi v. Dassonville [1974] ECR 837. Re: the importation into Belgium of a consignment of Scotch whisky purchased from French distributors without a certificate of origin required by Belgian law.

60 Lebtonen, para. 55. 